\title{
Clinical characteristic and therapy results of presumed ocular tuberculosis and their relation to HIV status
}

\author{
Rina L.D. Nora, Ratna Sitompul, Made Susiyanti, Lukman Edwar, Soedarman Sjamsoe \\ Department of Ophthalmology, Faculty of Medicine, Universitas Indonesia, Cipto Mangunkusumo Hospital Kirana, Jakarta, \\ Indonesia
}

\begin{abstract}
Abstrak
Latar belakang: Penegakan diagnosis tuberkulosis (TB) okular sulit dilakukan karena mikroorganisme tidak mudah diisolasi langsung dari mata, namun di sisi lain pemberian anti tuberkulosis berperan penting. Penelitian ini berusaha untuk mengidentifikasi tanda-tanda klinis di mata yang berhubungan dengan TB okular dan menilai keberhasilan terapi serta hubungannya dengan status HIV.
\end{abstract}

Metode: Data retrospektif diambil dari 56 rekam medis pasien dengan diagnosis presumed ocular TB di Rumah Sakit Cipto Mangunkusumo antara Januari 2006 sampai Desember 2011. Data demografi dan karakteristik klinis serta status HIV dicatat selama pengobatan berlangsung.

Hasil: Terdapat 39 pasien yang masuk kriteria inklusi dengan usia rerata 35,38 $\pm 13,1$ tahun dan rasio laki-laki terhadap perempuan 2:1. Kelainan mata unilateral didapatkan pada 26 (66,7\%) pasien. Dari seluruh pasien; 4 (10,3\%) uveitis anterior, 14 (35,9\%) uveitis posterior, 21 (66,7\%) panuveitis dan tidak ada yang menderita uveitis intermediet. Sebagian besar pasien (32/82,1\%) memiliki tuberkulosis di organ tubuh lain. Lima dari $8(62,5 \%)$ pasien dengan HIV positif memiliki tipe inflamasi granulomatosa dan 3 (37,5\%) tipe non-granulomatosa serta seluruh pasien dengan HIV positif memiliki tuberkulosis di organ lain. Tujuh pasien non-HIV, enam (85,7\%) diantaranya memiliki tipe inflamasi non-granulomatosa. Terapi dengan anti tuberculosis (ATT), kombinasi ATT dan steroid atau steroid saja bisa meningkatkan tajam penglihatan. Namun terapi steroid saja memiliki angka rekurensi yang sedikit lebih tinggi (1,4 0,89 episode inflamasi).

Kesimpulan: TB ocular pada penelitian ini memiliki manifestasi klinis yang sangat bervariasi. Tipe inflamasi nongranulomatosa lebih banyak pada pasien HIV negatif dan tipe inflamasi granulomatosa pada pasien HIV positif. Pasien HIV positif selalu disertai manifestasi TB di organ lain. Terapi dengan steroid saja dapat meningkatkan tajam penglihatan tapi diikuti dengan angka rekurensi yang sedikit lebih tinggi. (Med J Indones. 2012;21:214-9)

\begin{abstract}
Background: Ocular tuberculosis (TB) emerges as an important cause of intraocular inflammation, partly due to the increasing number of HIV/AIDS patients. This study attempts to identify ocular signs that are associated with ocular TB and assess the efficacy of the treatment and their relation to HIV status.

Methods: Medical records of all 56 patients diagnosed with presumed ocular TB in Cipto Mangunkusumo Hospital between January 2006 and December 2011 were reviewed. Demographic and clinical characteristics and HIV status were recorded as well as efficacy of treatments given.

Results: There were 39 patients included with mean age $35.38 \pm 13.1$ and male to female ratio was $2: 1$. Unilateral involvement was in $26(66.7 \%)$ patients. From all, four (10.3\%) had anterior uveitis, $14(35.9 \%)$ posterior uveitis, $21(53.8 \%)$ panuveitis, and none had intermediate uveitis. Most of them (32/82.1\%) have concurrent other organ TB. Five out of 8 (62.5\%) HIV positive patients had granulomatous inflammation and $3(37.5 \%)$ had non-granulomatous inflammation and all eight of them had concurrent other organ TB. The other 7 known non-HIV patients, six (85.7\%) have non-granulomatous inflammation. Treatment with anti-tubercular therapy (ATT), combination ATT and steroid or steroid alone increased visual acuity. However steroid alone was slightly have more frequent recurrences (1.4 \pm 0.89 episodes of inflammation).

Conclusion: Ocular TB in our study had variable clinical manifestations and ocular inflammation was predominantly non-granulomatous in HIV negative patients and granulomatous in HIV infected patients. All HIV positive patients the ocular TB was always accompanied by manifestations in other organs. The treatment with steroids solely resulted in improved vision but was characterized by frequent recurrences. (Med J Indones. 2012;21:214-9)
\end{abstract}

Keywords: HIV/AIDS, ocular tuberculosis, uveitis

Tuberculosis (TB) still has a high morbidity and mortality worldwide for that reason the World Health Organization (WHO) has declared TB to be a global emergency. Indonesia ranks fourth on WHO's Global Tuberculosis Control Report 2011 list of 22 highburden TB countries. New and relapsed TB cases were estimated around 300,659. Pulmonary localization is present in the majority of cases and around $18 \%$ are extrapulmonary. ${ }^{1}$ In recent years the proportion of extra pulmonary tuberculosis has increased in immunocompromised individuals, up to $50 \%$ in patients who have both AIDS and TB. ${ }^{2,3}$ Hence ocular involvements in TB may emerge as an important cause of intraocular inflammation.

The true prevalence of ocular TB is hard to obtain, due to the lack of uniform diagnostic criteria and difficulty of confirming the diagnosis by laboratory methods. 
A common clinical manifestation of intraocular TB is posterior uveitis, mimicking various uveitis entities, including multifocal choroiditis, serpiginous choroiditis, retinal vasculitis, and mass lesion in the choroid or subretinal abscess. Establishing a diagnosis of ocular TB in these cases may be challenging because many patients may lack systemic or pulmonary symptoms and some may have a chest radiograph without signs of TB and even a negative response on a tuberculin skin test. ${ }^{4-6}$ The beneficial role of long term administration of anti TB drugs along with immunosuppressive drugs was repeatedly noted in such cases. ${ }^{7-9}$ The aim of this study is to identify the typical ocular signs that are associated with TB (if any) and describe the efficacy of various treatments.

\section{METHODS}

We performed a retrospective study of 1004 patients diagnosed with uveitis between January 2006 and December 2011 in Infection and Immunology Division, Ophthalmology Department, Universitas Indonesia, Cipto Mangunkusumo Hospital. Patients were included in the study if the working diagnosis was ocular TB and the patients fulfilled the criteria of presumed or confirmed ocular TB. We used the criteria proposed by Gupta et $\mathrm{al}^{10}$ that consists of clinical signs presuming ocular TB, ocular investigation to prove the existence of $M$. tuberculosis in the eye, systemic investigations (Mantoux test and radiographic evidence of pulmonary or extrapulmonary TB), exclusions of other disease entities and therapeutic response test to anti-tubercular therapy (ATT).

Any one or more of the clinical signs in combination with any of the positive test of ocular investigation could be considered a confirmed (definitive) case of intraocular tuberculosis. Any one or more of the clinical signs in combination with any of the positive tests of systemic investigation or a positive therapeutic trial in combination with exclusion of other disease entities could be considered presumed ocular TB. If the patient had a history of ATT previously in other hospital we included the patient as a presumed ocular TB.

Data was extracted from clinical records, including age, sex, Mantoux test, chest X-ray result, history of ATT and immunosuppressive drugs. HIV status was extracted from the laboratory result and CD4 was noted. Positive HIV if the result from the screening test is positive. Ocular status included visual acuity and various clinical manifestations. Visual acuity was done with Snellen chart in meter and will be converted to decimal.

Clinical appearance of inflammation was further classified as granulomatous and non-granulomatous.
In the anterior segment; the appearance of posterior synechiae, mutton fat and iris nodules were considered as granulomatous signs. Choroidal tubercles, choroidal tuberculoma, subretinal abscess were considered granulomatous. Clinical signs such as small to medium keratic precipitates, serpiginous-like choroiditis, retinitis and vasculitis were considered as non-granulomatous.

Treatment was categorized into groups of patients who received only ATT, ATT and steroid in immunosuppressive dose or steroid only.

\section{RESULTS}

Ocular TB was diagnosed in 56 patients according to the Gupta's criteria. Three patients were excluded because their ocular inflammation was attributed to other disease entity (syphilis, rhegmatogenous retinal detachment and ATT drug induced uveitis). Fourteen patients were excluded because they only attended the outpatient clinic once and their follow up was not available. There were 39 cases of ocular TB included in this study. This group comprises $3.9 \%$ of the total 1004 uveitis patients came to Infection and Immunology Division during this period. All of the cases were presumed ocular TB and none of them underwent intraocular fluid analysis to confirm the existence of $M$. tuberculosis.

\begin{tabular}{lcc} 
Table 1. Patient demographic & & \\
\hline Demography & $\mathrm{n}$ & $\%$ \\
\hline Gender & & \\
$\quad$ Male & 26 & 66.7 \\
$\quad$ Female & 13 & 33.3 \\
$\quad$ Age (years old) & & \\
$\quad<16$ & 1 & 2.6 \\
$16-25$ & 7 & 17.9 \\
$25-45$ & 23 & 59.0 \\
$45-65$ & 6 & 15.4 \\
$>65$ & 2 & 5.1 \\
\hline
\end{tabular}

General data are given in table 1. Mean age of patients was $35 \pm 13$ years and male-to-female ratio was 2:1. More than $50 \%$ of patients manifested between 25 and 45 years. Unilateral involvement was present in 26 patients $(66.7 \%)$ and bilateral in 13 patients $(33.3 \%)$. Systemic TB signs were found in 32 patients and 7 had solely presumed ocular TB.

Ocular features are illustrated in table 2. Location of inflammation varied, specifically $10.3 \%$ anterior uveitis, $35.9 \%$ posterior uveitis, $53.8 \%$ panuveitis, but none had an intermediate uveitis. Distribution of type and location of inflammation did not differ between the patients with systemic TB signs and those with ocular 
Table 2. Distribution of ocular manifestation according to uveitis location

\begin{tabular}{|c|c|c|c|c|}
\hline & $\begin{array}{c}\text { Anterior } \\
\text { Uveitis } \\
\mathrm{n}(\%)\end{array}$ & $\begin{array}{c}\text { Intermediate } \\
\text { Uveitis } \\
\mathrm{n}(\%)\end{array}$ & $\begin{array}{c}\text { Posterior } \\
\text { Uveitis } \\
\mathrm{n}(\%)\end{array}$ & $\begin{array}{c}\text { Panuveitis } \\
\mathrm{n}(\%)\end{array}$ \\
\hline \multicolumn{5}{|l|}{ Anterior segment } \\
\hline Mutton fat keratic percipitates & $1(25)$ & & & $5(23.8)$ \\
\hline Posterior synechiae & $1(25)$ & & & $7(33.3)$ \\
\hline Non granulomatous inflammation & $2(50)$ & & & $9(42.9)$ \\
\hline \multicolumn{5}{|l|}{ Posterior segment } \\
\hline Choroidal infiltrate, tubercle, tuberculoma & & & $9(64.4)$ & $2(9.5)$ \\
\hline Retinitis and retinal vasculitis & & & $3(21.4)$ & $5(23.8)$ \\
\hline Serpiginous like choroiditis & & & $1(7.1)$ & \\
\hline Neuroretinitis or neuropathy & & & $1(7.1)$ & \\
\hline Vitreus haze & & & & $3(14.4)$ \\
\hline Retinal detachment & & & & $2(9.5)$ \\
\hline Hard to be evaluated & & & & $9(42.8)$ \\
\hline \multicolumn{5}{|l|}{ Laterality } \\
\hline Unilateral & $4(100)$ & & $9(64.3)$ & $13(61.9)$ \\
\hline Bilateral & $0(0)$ & & $5(35.7)$ & $8(38.1)$ \\
\hline
\end{tabular}

Table 3. Manifestation of ocular TB compare to other organ involvement

\begin{tabular}{lcc}
\hline \multicolumn{1}{c}{ TB Manifestation } & $\begin{array}{c}\text { Granulomatous } \\
\mathrm{n}(\%)\end{array}$ & $\begin{array}{c}\text { Non-Granulomatous } \\
\mathrm{n}(\%)\end{array}$ \\
\hline $\begin{array}{l}\text { HIV positive } \\
\quad \text { Concurrent systemic and eye manifestation } \\
\quad \text { Solitary eye manifestation }\end{array}$ & $5(62.5)$ & $3(37.5)$ \\
HIV negative & $0(0)$ & $0(0)$ \\
$\quad$ Concurrent systemic and eye manifestations & $1(16.7)$ & $5(83.3)$ \\
$\quad$ Solitary eye manifestation & $0(0)$ & $1(100)$ \\
\end{tabular}

TB solely. In patients with concurrent systemic and eye manifestation, granulomatous inflammation was found in 17 patients $(53.1 \%)$ and 15 patients $(46.9 \%)$ had non-granulomatous inflammation. Whereas in patients that have solitary eye manifestations, 4 patients $(57.1 \%)$ had granulomatous inflammation and 3 patients $(42.9 \%)$ had non-granulomatous inflammation.

In our study, there were only 15 patients who were investigated for their HIV status. Among them there were 8 cases of HIV positive but the CD4 data couldn't be found. In HIV positive cases, the manifestations tended to be systemic and the manifestation in the eye was predominantly granulomatous. In HIV negative patients, non-granulomatous inflammation was more common (Table 3 ).

Most of the non-granulomatous inflammations were diagnosed as ocular TB due to the chest X-ray or chest CT-scan result. Whereas in granulomatous inflammation, history taking and clinical appearances has render a patient to ocular TB diagnosis.

In HIV positive patients, the inflammation tended to be in the posterior and most of them were granulomatous. Meanwhile HIV negative patients tended to have panuveitis an the inflammation was non granulomatous (Figure 1).

Therapy results of our patients are illustrated in table 4 . There were 20 treated cases with available therapy followup. Patients who received only steroids (topical steroid for anterior uveitis or both topical and systemic steroid for posterior and panuveitis) had slightly better improvement of visual acuity (but had also better initial visual acuity) and had slightly higher number of recurrences.

In HIV positive patients, treatment with ATT alone has increased their visual acuity. If ATT was combined with corticosteroids, the visual acuity deteriorated and inflammation recurred more often (Table 5). 
Table 4. Result of therapy

\begin{tabular}{ccccc}
\hline Therapy (n) & $\begin{array}{c}\text { Visual Acuity } \\
\text { first visit }\end{array}$ & $\begin{array}{c}\text { Visual Acuity } \\
\text { last visit }\end{array}$ & $\begin{array}{c}\text { Mean difference } \\
\text { of VA }\end{array}$ & $\begin{array}{c}\text { Number of } \\
\text { episodes }\end{array}$ \\
\hline Only ATT (5) & $0.54(0.55)$ & $0.64(0.58)$ & $0.10(0.34)$ & $1.0(0)$ \\
ATT + steroid (10) & $0.09(0.15)$ & $0.11(0.13)$ & $0.02(0.16)$ & $1.3(0.67)$ \\
Only steroid (5) & $0.45(0.60)$ & $0.55(0.47)$ & $0.11(0.52)$ & $1.4(0.89)$ \\
\hline
\end{tabular}

Table 5. Comparison of therapy results between HIV positive and negative patients

\begin{tabular}{lcccc}
\hline Therapy (n) & $\begin{array}{c}\text { Visual Acuity } \\
\text { first visit }\end{array}$ & $\begin{array}{c}\text { Visual Acuity } \\
\text { last visit }\end{array}$ & $\begin{array}{c}\text { Mean difference } \\
\text { of VA }\end{array}$ & $\begin{array}{c}\text { Number of } \\
\text { episodes }\end{array}$ \\
\hline HIV Negative & & & & \\
Only ATT (0) & $0(0)$ & $0(0)$ & $0(0)$ & $0(0)$ \\
ATT + steroid (4) & $0.05(0.08)$ & $0.09(0.11)$ & $0.04(0.03)$ & $1.5(1.00)$ \\
Only steroid (1) & $0.02(-)$ & $1.0(-)$ & $0.98(-)$ & $3(-)$ \\
HIV Positive & & & & \\
Only ATT (3) & $0.57(0.6)$ & $0.74(0.63)$ & $0.17(0.47)$ & $1(0)$ \\
ATT + steroid (1) & $0.05(0)$ & $0(0)$ & $-0.05(0)$ & $3(0)$ \\
Only steroid (0) & $0(0)$ & $0(0)$ & $0(0)$ & $0(0)$ \\
\hline
\end{tabular}

\section{DISCUSSION}

Presumed ocular tuberculosis in our series had variable clinical manifestations and ocular inflammation was predominantly non-granulomatous in HIV negative patients and granulomatous in HIV infected patients. There are wide spectrum of ocular TB manifestation such as anterior uveitis, mutton fat keratic precipitates, iris nodules, snowball, snow banking, vasculitis, multifocal choroiditis, serpiginous-like choroiditis and tuberculous optic neuropathy. ${ }^{11-13}$ Gupta et al tried to compare the clinical signs of presumed ocular TB with other uveitis of know cause. They found that broad-based posterior synechiae, retinal vasculitis with or without choroiditis and serpiginous-like choroiditis were seen significantly more common in patient with presumed ocular TB. ${ }^{5}$ However the diagnostic accuracy for these clinical signs is $64 \%, 59 \%$ and $59 \%$ respectively.

The lack of specific presentation of ocular TB and difficulty of direct microbial identification from the eye made the diagnosis challenging, especially if it is not associated with systemic active TB. Wroblewski et al reported a retrospective study of 37 histopathology result from eye specimens that were positive for Mycobacterium tuberculosis. They noticed the paucity of organisms' nature of ocular TB cases that even with only 1 or 2 organisms associated with or near a giant cell or near an area of necrosis. Among those patients, in 17 data of available mantoux tests (TST), ten showed positive result $(60 \%)$ and 7 showed negative results (40\%). In the 7 TST-negative patients, four chest radiographs were obtained, of which 2 showed normal results and other 2 showed apical thickening and upper lobe fibrosis. ${ }^{14}$ Therefore there is a need for diagnostic test that could detect the active immune reaction due to extrapulmonary Mycobacterium tuberculosis. ${ }^{15-19}$

The presentation of granulomatous inflammation in HIV/AIDS patients in study are in accordance to several other studies which were mainly choroidal granulomas and tubercles. ${ }^{20-27}$ Our findings that ocular TB in HIV/ AIDS patients all have systemic manifestation are in accordance to Babu et al study that found in HIV/ AIDS patients, all ocular TB patients have pulmonary $\mathrm{TB}$, and among them two cases have coexistent central nervous system TB and one case had abdominal TB. In that study also found that the CD4+ cell counts ranged from 14 to 560 cells $/ \mu \mathrm{L}$ with mean 160.85 cells $/ \mu \mathrm{L}$. In this study CD4+ cell counts data couldn't be retrieved which made it one of the study limitations. One of the HIV/AIDS patient treated with steroid and ATT and the visual acuity was worsen to no light perception. The steroid was given prior the knowledge of HIV status, therefore there should be a caution to check the HIV status in every presumed ocular tuberculosis with systemic tuberculosis especially if the patients have HIV-related signs and history suggestive of high risk of HIV exposure. ${ }^{28}$

Our observations of administration of steroids without ATT were associated with decrease of visual acuity and more frequent recurrences. The limited increase of visual acuity in patients treated by ATT can be explained by selection bias (lower initial visual acuities compared to other groups). Our results document that 


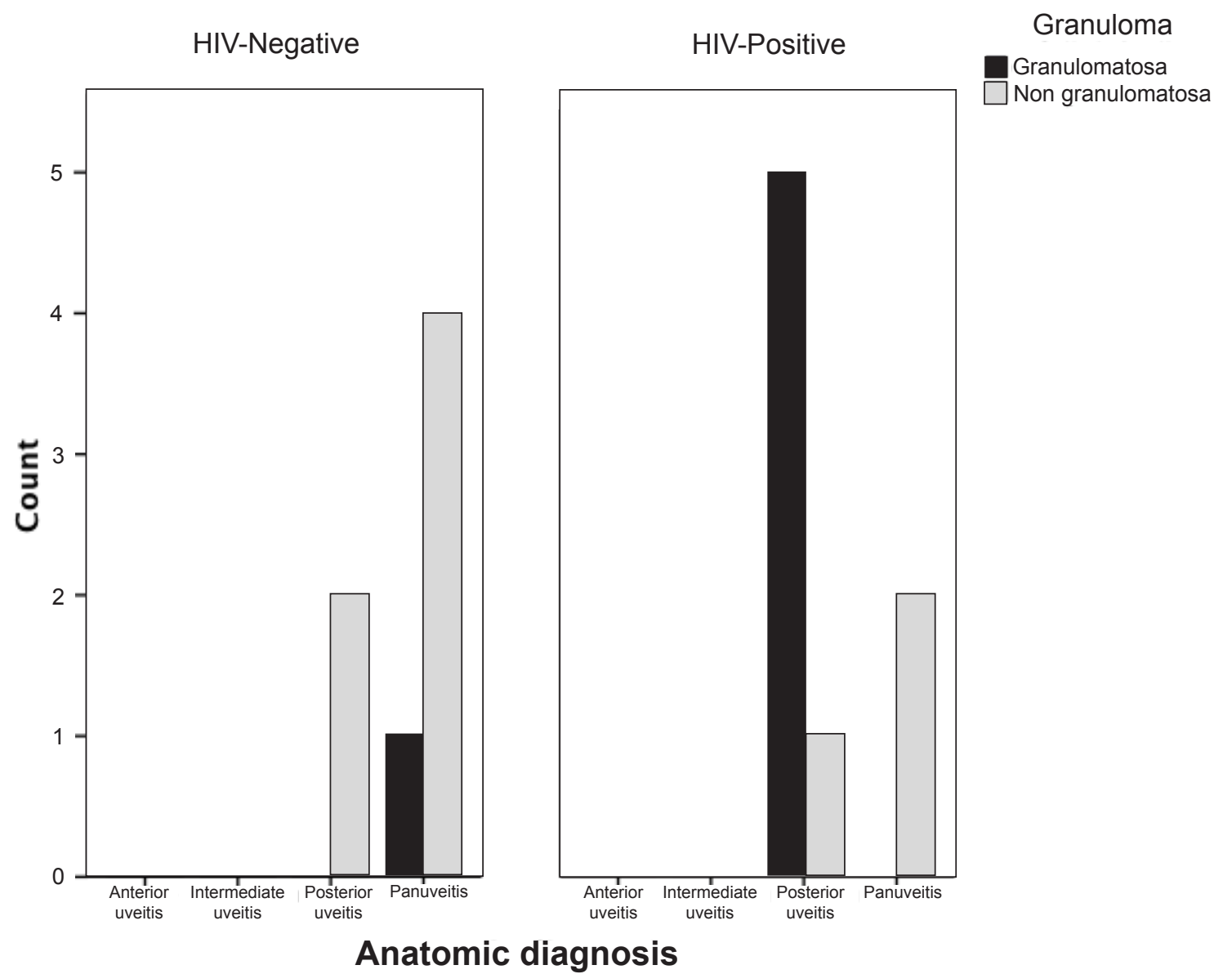

Figure 1. Ocular manifestation of TB in HIV negative and positive patients

ATT was the only medication that worked well on granulomatous ocular TB in HIV positive patients. Bansal et al observed that the patients with ocular TB treated with anti-tubercular therapy with corticosteroids had decreased risk of developing recurrence of uveitis by approximately two-thirds as compared to those treated with corticosteroids alone. ${ }^{7}$ Ang et al found that patients with uveitis attributed to TB who were treated with ATT longer than 9 months, had a 11-fold reduction in the likelihood of recurrences. ${ }^{8}$ Zhang et al also noted in their series the importance of ATT in maximally maintain visual acuity. ${ }^{11}$

There are several limitations in our study due to the incomplete data from the medical records, detail medication of ATT, and the length of follow-ups. Further, the limited number of patients included as well as the fact that not all patients were assessed for HIV might have influenced our results. Overall, ocular TB in our study had variable clinical manifestations and ocular inflammation was predominantly non-granulomatous in HIV negative patients and granulomatous in HIV infected patients. All HIV positive patients the ocular
TB was always accompanied by manifestations in other organs. The treatment with steroids solely resulted in improved vision but was characterized by frequent recurrences.

\section{Acknowledgment}

We thank to dr. Niluh Archi Sri Ramandari.

\section{REFERENCES}

1. World Health Organization. Global tuberculosis control: WHO report 2011. France: World Health Organization; 2011.

2. Golden MP, Vikram HR. Extrapulmonary tuberculosis: an overview. Am Fam Physician. 2005;72(9):1761-8.

3. Jones BE, Young SM, Antoniskis D, Davidson PT, Kramer F, Barnes PF. Relationship of the manifestations of tuberculosis to CD4 cell counts in patients with human immunodeficiency virus infection. Am Rev Respir Dis. 1993;148(5):1292-7.

4. Nayak S, Basu S, Singh MK. Presumed tubercular retinal vasculitis with serpiginous-like choroiditis in the other eye. Ocul Immunol Inflamm. 2011;19(5):361-2. 
5. Gupta V, Gupta A, Arora S, Bambery P, Dogra MR, Agarwal A. Presumed tubercular serpiginouslike choroiditis: clinical presentations and management. Ophthalmology. 2003;110(9):1744-9.

6. Rao NA, Albini TA, Kumaradas M, Pinn ML, Fraig MM, Karakousis PC. Experimental ocular tuberculosis in guinea pigs. Arch Ophthalmol. 2009;127(9):1162-6.

7. Bansal R, Gupta A, Gupta V, Dogra MR, Bambery P, Arora SK. Role of anti-tubercular therapy in uveitis with latent/manifest tuberculosis. Am J Ophthalmol. 2008;146(5):772-9.

8. Ang M, Hedayatfar A, Wong W, Chee SP. Duration of anti-tubercular therapy in uveitis associated with latent tuberculosis: a case-control study. $\mathrm{Br} \mathrm{J}$ Ophthalmol. 2012;96(3):332-6.

9. Gupta V, Bansal R, Gupta A. Continuous progression of tubercular serpiginous-like choroiditis after initiating antituberculosis treatment. Am J Ophthalmol. 2011;152(5):857-63.e2

10. Gupta V, Gupta A, Rao NA. Intraocular tuberculosis--an update. Surv Ophthalmol. 2007;52(6):561-87.

11. Zhang M, Zhang J, Liu Y. Clinical presentations and therapeutic effect of presumed choroidal tuberculosis. Retina. 2012;32(4):805-13.

12. Sudharshan S, Ganesh SK, Balu G, Mahalakshmi B, Therese LK, Madhavan HN, et al. Utility of QuantiFERON®-TB Gold test in diagnosis and management of suspected tubercular uveitis in India. Int Ophthalmol. 2012;32(3):217-23.

13. Davis EJ, Rathinam SR, Okada AA, Tow SL, Petrushkin $\mathrm{H}$, Graham EM, et al. Clinical spectrum of tuberculous optic neuropathy. $\mathrm{J}$ Ophthalmic Inflamm Infect. 2012;2:183-9.

14. Wroblewski KJ, Hidayat AA, Neafie RC, Rao NA, Zapor M. Ocular tuberculosis: a clinicopathologic and molecular study. Ophthalmology. 2011;118(4):772-7.

15. Ang M, Wong W, Ngan CC, Chee SP. Interferon-gamma release assay as a diagnostic test for tuberculosis-associated uveitis. Eye (Lond). 2012;26(5):658-65.

16. Cordero-Coma M, Calleja S, Torres HE, del Barrio I, Franco M, Yilmaz T, et al. The value of an immune response to Mycobacterium tuberculosis in patients with chronic posterior uveitis revisited: utility of the new IGRAs. Eye (Lond). 2010;24(1):36-43.
17. Goletti D, Sester M. Screening for latent infection with Mycobacterium tuberculosis: a plea for targeted testing in low endemic regions. Expert Rev Mol Diagn. 2012;12(3):231-4.

18. Mack U, Migliori GB, Sester M, Rieder HL, Ehlers S, Goletti D, et al. LTBI: latent tuberculosis infection or lasting immune responses to $M$. tuberculosis? A TBNET consensus statement. Eur Respir J. 2009;33(5):956-73.

19. Gineys R, Bodaghi B, Carcelain G, Cassoux N, Boutin le TH, Amoura Z, et al. QuantiFERON-TB gold cut-off value: implications for the management of tuberculosis-related ocular inflammation. Am J Ophthalmol. 2011;152(3):43340.e1.

20. Babu RB, Sudharshan S, Kumarasamy N, Therese L, Biswas J. Ocular tuberculosis in acquired immunodeficiency syndrome. Am J Ophthalmol. 2006;142(3):413-8.

21. Beare NA, Kublin JG, Lewis DK, Schijffelen MJ, Peters RP, Joaki G, et al. Ocular disease in patients with tuberculosis and HIV presenting with fever in Africa. Br J Ophthalmol. 2002;86(10):1076-9.

22. Bouza E, Merino P, Munoz P, Sanchez-Carrillo C, Yanez J, Cortes C. Ocular tuberculosis. A prospective study in a general hospital. Medicine (Baltimore). 1997;76(1):53-61.

23. DiLoreto DA Jr, Rao NA. Solitary nonreactive choroidal tuberculoma in a patient with acquired immune deficiency syndrome. Am J Ophthalmol. 2001;131(1):138-40.

24. Mehta S, Gilada IS. Ocular tuberculosis in acquired immune deficiency syndrome (AIDS). Ocul Immunol Inflamm. 2005;13(1):87-9.

25. Muccioli C, Belfort R Jr. Presumed ocular and central nervous system tuberculosis in a patient with the acquired immunodeficiency syndrome. Am J Ophthalmol. 1996;121(2):217-9.

26. Shimakawa M. [Choroidal tuberculoma in a patient with acquired immunodeficiency syndrome]. Jpn J Ophthalmol. 2000;44(6):697. Japanese.

27. Welton TH, Townsend JC, Bright DC, Anderson SF, Nguyen AT, Ilsen PF. Presumed ocular tuberculosis in an AIDS patient. J Am Optom Assoc. 1996;67(6):350-7.

28. Tuberculosis Coalition for Technical Assistance. International standards for tuberculosis care (ISTC). Standard 12. The Hague: Tuberculosis Coalition for Technical Assistance; 2006. 